The Social Sciences 7 (4): 625-629, 2012

ISSN: $1818-5800$

(C) Medwell Journals, 2012

\title{
Role of Spiritual Aspect in the Learning Process of Islamic Studies Student
}

\author{
Salasiah Hanin Hamjah, Rosmawati Mohamad Rasit and Fariza Md. Sham \\ Department of Da'wah and Leadership Studies, Faculty of Islamic Studies, \\ Universiti Kebangsaan Malaysia, 43650 Bangi, Selangor, Malaysia
}

\begin{abstract}
The spiritual aspect is a matter which students need to pay attention to, regardless of which studies or level they are in. Neglect of this aspect may cause students to lose sight of their learning objectives and lack of motivation. Therefore, this research is carried out to study the forms of spiritual exercise practiced by students of the Faculty of Islamic Studies (FPI), National University of Malaysia (UKM) to identify the forms of spiritual exercise which in the respondents' view can increase student learning motivation and to analyze the relation between spiritual practice and student academic achievement. Through random sampling, a total of 291 students from the 2nd and 3rd year undergraduates are selected. Data collected from questionnaires is analyzed using descriptive statistics. The results of this study show some forms of spiritual exercise related to learning practiced by FPI students. This research also finds some forms of spiritual exercise which respondents admit have helped in improving their learning motivation and there is a significant relation between student spiritual practice and academic achievement $(\mathrm{r}=0.262 ; \mathrm{p}<0.01)$.
\end{abstract}

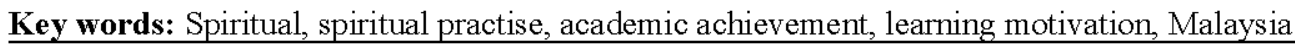

\section{INTRODUCTION}

The spiritual aspect plays an important role in a student's life, especially students of Islamic Studies. Lack of a proper emphasis on the spiritual aspect may cause a student to lack learning motivation and lose proper learning objective. This research is done to determine whether the spiritual aspect as a form of inner drive has a positive impact on the learning process, specifically in improving learning motivation and academic achievement. Spirituality is difficult to accurately define. Each person has his or her own opinions and thoughts relating to spiritual conceptions. It is more varied in perception than various dimensions of religious belief, culture and custom. Hence, it is not surprising that various different definitions of spirituality have been phrased by researchers in the West. Jankowski (2002) defines spirituality as referring to values and beliefs related to religious doctrines involving beliefs about the meaning of life, reality and death as well as feelings of dependence on others or God. Faiver et al. (2000) defines spirituality as extraordinary strength capable of causing change from difficulty to ease from enmity to cooperation and from incompatibility to love. It is also an inner quality in man which connects him to other individuals and helps him to adjust himself to life's situations. In the West, most researchers see spirituality as different from religion that is spirituality is not religion. Spirituality is focused on what goes on in the heart while not all aspects of religion are related to spirituality (Maher and Hunt, 1993). This situation does not exist in Islam, whereby spiritual and religious aspects are seen as integrated and inseparable (Nurul Ain, 2008).

In Islam, the spiritual aspect or al-nafsiyy is seen as involving a combination of heart, psyche, mind and soul. For example, Al-Ghazali (2000) in describing the meaning of spirituality explained that there are four elements which form the basis of spirituality of every human-al-nafs (psyche), al-qalb (heart), al-Ruh (soul) and al-'aql (mind). According to him these 4 elements play a role in explaining the reality of the man who has the capacity to acquire knowledge. Further, discussion of spirituality is more focused on the heart (al-qalb) because the heart is like the king who rules the whole body of man. Hence, the Prophet $(\mathrm{PBUH})$ recommends his Ummah to safeguard the heart because the determinant of how good or bad a person is lying in the heart as stated in a Hadith of the Prophet (PBUH):

In the body of man is a piece of flesh. If the piece of flesh becomes good (reformed), the whole body becomes good but if it gets spoilt then the whole body gets spoilt and that is the heart (Hadith narrated by Bukhari)

Corresponding Author: Salasiah Hanin Hamjah, Department of Da'wah and Leadership Studies, Faculty of Islamic Studies, Universiti Kebangsaan Malaysia, 43650 Bangi, Selangor, Malaysia 
The outcome of this discussion explains that the spiritual aspect refers to the beliefs of a person, dependence on God and focuses on what is happening in the heart. Based on this meaning this research attempts to examine the spiritual practice of students in FPI and its effect on improvement of motivation and academic achievement.

Many researchers such as Revell (2008), Daniliuk et al. (2010), Campbell (2010), Buchanan (2009) and others are beginning to be aware of the importance of the spiritual aspect in education. A study by Revell (2008) in Boston and Chicago proved that there is a need to apply spiritual values in school education as one of the responses to negative symptoms resulting from modernisation of society. In addition, a study by Daniliuk et al. (2010) finds that a new school in Russia needs to implement a spiritual component in the development of Russian personality. In fact in the public charter of Russian education, spirituality is regarded as the main key of education in Russia and Campbell (2010) in his doctoral research recommends a transformation in the educational process. Educational theories need to apply the role of spirituality as a main factor in the educational process. These studies show that that there is a need to include a spiritual element in school education. However, these studies so far have only stated the importance of the spiritual aspect but have not yet explored the role played by spirituality in contributing to student motivation improvement and academic achievement.

A study which correlates spirituality and academic achievement has also been conducted by Steward and Jo (1998), Hodge and Cuddeback (2010), Saidy et al. (2009) and so on. However, there is not much research which specifically discusses the role of the spiritual aspect in improving student motivation. This clearly shows the importance of conducting research such as this to prove that the spiritual aspect plays an important role in the life of a student.

Objectives of study: Among the objectives of this research is to examine the spiritual exercises practiced in the daily routine of FPI students. The purpose of this research is to identify the role of spirituality in improving motivation and to analyze the correlation between spiritual practice and academic achievement of FPI students.

\section{MATERIALS AND METHODS}

This study is in the form of a study survey. A total of 291 students are chosen as samples from a total of 715 students from the Faculty of Islamic Studies (FPI). Sample selection is done through random sampling. The respondents in this study comprise of 291 2nd and 3rd year students who are in the 2 nd semester for the academic session of 2009/2010. Total 141 (48.5\%) respondents are 2 nd year students whereas the remaining $150(51.5 \%)$ are 3 rd year students. $102(35.1 \%)$ are male respondents and the remaining 189 (64.9\%) respondents are female. They represent 5 departments in the Faculty of Islamic Studies: Shariah, Usuluddin and Philosophy, Arabic Studies and Islamic Civilization, Quran and Sunnah Studies and Da'wah and Leadership Studies Departments. $24.4 \%$ (17) of the respondents are from Kelantan, followed by Kedah with 33 respondents $(11.3 \%)$. Indonesians record the lowest number of respondents which makes up $0.3 \%$. This study uses self-administered questionnaires that are constructed based on the research questions and objectives. Using SPSS 16.0, the data are analyzed quantitatively through descriptive statistics and is presented in the form of a percentage, frequency and mean.

\section{RESULTS AND DISCUSSION}

The research outcome finds that $73.2 \%$ (213 persons) of respondents read al-Quran once or twice a week, followed by $65.6 \%$ (191 persons) who exercise muhasabah (self-accountability) once or twice a day and more than half of respondents, 55.3\% (161 persons) perform solat hajat (prayers of intention) or qiyam al-lail (night prayers) once or twice a week. Research outcome also finds $53.6 \%$ (156 persons) of respondents perform solat jemaah (congregational prayers) once or twice a day and $44.0 \%$ (128 persons) of respondents perform solat sunat rawatib (optional rawatib prayers) once or twice a day. In addition, 10.6\% (31 persons) FPI students exercise muhasabah (self-accountability) $>6$ times a day, $5.5 \%$ (16 persons) FPI students perform solat hajat (prayers of intention) or qiyam al-lail $>6$ times a week, 3.4\% (10 persons) perform solat jemaah (congregational prayers) each prayer time and $3.1 \%$ ( 9 persons) read al-Quran $>6$ times a day. This finding shows that $36.4 \%$ (106 persons) do not perform solat sunat rawatib (optional rawatib prayers), 29.5\% (86 persons) do not solat jemaah (pray in congregation), $17.9 \%$ (52 persons) do not perform solat hajat (prayers of intention) or qiyam al-lail (night prayers), 7.9\% (23 persons) do not muhasabah (self-accountability) and $2.7 \%$ ( 8 persons) do not read al-Quran daily.

Even though, the findings show that there are among FPI students who do not perform solat sunat rawatib (optional rawatib prayers) do not solat jemaah (pray in congregation) do not perform solat hajat (prayers of intention) and muhasabah (self-accountability) this number is small. On the whole, majority of research respondents perform spiritual practice such as reading 
The Soc. Sci., 7 (4): 625-629, 2012

\begin{tabular}{|c|c|c|c|c|c|c|}
\hline \multirow[b]{2}{*}{ Forms of daily spiritual exercise } & \multicolumn{5}{|c|}{ Frequency of performance (times) } & \multirow[b]{2}{*}{ Total } \\
\hline & None & $1-2 \mathrm{x}$ & $3-4 \mathrm{x}$ & $5 \mathrm{x}$ & $6 \mathrm{x}$ and above & \\
\hline Solat hajat/Qiyam al-lail in a week & $52(17.9 \%)$ & $161(55.3 \%)$ & $55(18.9 \%)$ & $7(2.4 \%)$ & $16(5.5 \%)$ & $291(100 \%)$ \\
\hline Reading al-Quran in a day & $8(2.7 \%)$ & $213(73.2 \%)$ & $41(14.1 \%)$ & $20(6.9 \%)$ & $9(3.1 \%)$ & $291(100 \%)$ \\
\hline Perform Solat Sunat Rawatib in a day & $106(36.4 \%)$ & $128(44.0 \%)$ & $33(11.3 \%)$ & $16(5.5 \%)$ & $8(2.7 \%)$ & $291(100 \%)$ \\
\hline Perform Solat Jemaah in a day & $86(29.5 \%)$ & $156(53.6 \%)$ & $39(13.4 \%)$ & $10(3.4 \%)$ & $0(0.0 \%)$ & $291(100 \%)$ \\
\hline Exercise Muhasabah (self-accountability) in a day & $23(7.9 \%)$ & $191(65.6 \%)$ & $23(7.9 \%)$ & $23(7.9 \%)$ & $31(10.6 \%)$ & $291(100 \%)$ \\
\hline
\end{tabular}

Table 2: Spiritual exercises related to learning

\begin{tabular}{|c|c|c|c|c|c|c|}
\hline Spiritual exercise & Strongly disagree & Disagree & Not sure & Agree & Strongly agree & Mean \\
\hline I always begin my studies with reading doa & $0(0.0 \%)$ & $7(2.4 \%)$ & $37(12.7 \%)$ & $150(51.5 \%)$ & $97(33.3 \%)$ & 4.16 \\
\hline $\begin{array}{l}\text { I am better motivated to study by tawakkal } \\
\text { (putting trust in Allah SWT) }\end{array}$ & $0(0.0 \%)$ & $1(0.3 \%)$ & $23(7.9 \%)$ & $143(49.1 \%)$ & $124(42.6 \%)$ & 4.34 \\
\hline I feel ashamed in the sight of Allah if I fail in & $3(1$ & $11(3$ & 57( & 140 & $\%)$ & 4.00 \\
\hline $\begin{array}{l}\text { I am content with Allah SWT even if I fail in my studies } \\
\text { after working hard }\end{array}$ & $1(0.3 \%)$ & $1(0.3 \%)$ & $18(6.2 \%)$ & $138(47.4 \%)$ & $133(45.7 \%)$ & 4.38 \\
\hline I am grateful to Allah SWT after succeeding in my studies & $0(0.0 \%)$ & $2(0.7 \%)$ & $6(2.1 \%)$ & $91(31.3 \%)$ & $192(66.0 \%)$ & 4.63 \\
\hline
\end{tabular}

Questionnaire, 2010

al-Quran, perform solat sunat rawatib (optional rawatib prayers), solat berjemaah (pray in congregation) and exercise muhasabah (self-accountability) even if only once or twice a day (Table 1).

In addition, the research outcome finds some forms of spiritual exercises directly related to learning activity of respondents (Table 2). About 97.3\% (283 persons) of respondents agree and strongly agree with the statement I am grateful after succeeding in my studies, $93.1 \%$ (271 persons) agree and strongly agree with the item I am content with Allah SWT even if I fail in my studies after working hard, 91.7\% (267 persons) agree and strongly agree with the item I am better motivated after tawakkal (putting trust in Allah SWT), 84.8\% (247 persons) agree and strongly agree with the item I always begin studying by reading dua and $75.6 \%$ (220 persons) agree and strongly agree with the item I feel ashamed in the sight of Allah if I fail in my studies.

On average, the highest mean value in this part can be seen in the item I am grateful to Allah SWT after succeeding in my studies (mean $=4.63$ ), followed by I am content with Allah SWT. Even if I fail in my studies after working hard (mean $=4.38$ ) and I am more motivated to study by tawakkal (putting trust in Allah SWT) (mean $=4.34)$. Many respondents state agreement (between mean 4.00-4.63) with the 5 items stated.

This finding clearly shows that among the daily and weekly spiritual exercises by FPI students are qiyam allail, solat sunat awwabin, reading al-Quran, congregational prayers and muhasabah (selfaccountability) and the spiritual exercise directly related to learning by respondents in this research is reading dua before beginning to study, tawakkal (putting trust in Allah) being content in failure despite having worked hard and gratitude to Allah for success in studies.
This research is also conducted to identify the spiritual exercises which may improve learning motivation among FPI students. I am more motivated when receiving family support and encouragement has the highest mean $($ mean $=4.5)$, followed by item I am more motivated to learn by tawakkal (putting trust in Allah SWT) (mean $=4.34$ ), followed next by item I am always motivated to learn because I always observe the 5 daily prayers (solat) (mean $=4.27$ ), next by item I am more motivated to learn because I always recite al-Quran (mean $=4.14$ ), next by item I will be more motivated when I am able to control my emotions and feelings (mean $=4.10$ ), next by item I will be more motivated when I am able to control my mind (mean $=3.95$ ) and the lowest mean is for item I am more motivated to learn because I perform the solat hajat/Qiyam al-lail $($ mean $=3.87)($ Table 3$)$.

This finding explains that the spiritual aspect which most contributes to improving learning motivation of FPI students is a family support and encouragement. Tawakkal, 5 times daily prayers and reading al-Quran also contributes to improving learning motivation of FPI students. The spiritual aspect relating to emotions is also important to improve learning motivation whereby respondents admit that when they are capable of controlling their emotions and thoughts, their learning motivation improves.

This finding shows that spiritual exercise such as tawakkal, performing prayers and reading al-Quran have an important role in improving learning motivation. This is in line with Islamic teachings whereby tawakkal will improve one's motivation in whatever one undertakes because tawakkal makes a person place a high reliance on Allah after putting one's best foot forward (Al-Ghazali 2000). This is in line with a Quranic verse which explains that Allah SWT commands His ummah to surrender 
The Soc. Sci., 7 (4): 625-629, 2012

Table 3: Spiritual aspect which may improve learning motivation of FPI students

\begin{tabular}{|c|c|c|c|c|c|c|}
\hline Spiritual exercise & Strongly disagree & Disagree & Not sure & Agree & Strongly agree & Mean \\
\hline $\begin{array}{l}\text { I will be more motivated when I am able } \\
\text { to control my mind }\end{array}$ & $2(0.75 \%)$ & $5(1.7 \%)$ & $47(16.2 \%)$ & $188(64.6 \%)$ & $49(16.8 \%)$ & 3.95 \\
\hline $\begin{array}{l}\text { I will be more motivated when I am able to } \\
\text { control my emotions and feelings }\end{array}$ & $1(0.35 \%)$ & $3(1.0 \%)$ & $30(10.3 \%)$ & $190(65.3 \%)$ & $67(23.0 \%)$ & 4.10 \\
\hline $\begin{array}{l}\text { I am always motivated to leam because I always } \\
\text { observe the } 5 \text { daily prayers (solah) }\end{array}$ & $0(0.0 \%)$ & $2(0.7 \%)$ & $21(7.2 \%)$ & $164(56.4 \%)$ & $104(35.7 \%)$ & 4.27 \\
\hline $\begin{array}{l}\text { I am more motivated to learn because I perform the } \\
\text { solat hajat/Qiyam al-lail }\end{array}$ & $1(0.3 \%)$ & $11(3.8 \%)$ & $70(24.1 \%)$ & $151(51.9 \%)$ & $58(19.9 \%)$ & 3.87 \\
\hline otivinted to lom & & & 35 & & & 4.14 \\
\hline & $0.0 \%)$ & & $23(7.9 \%)$ & $143(49.1 \%)$ & $124(42.6 \%)$ & 4.34 \\
\hline I am more motivated with family support and encoura & $0(0.0 \%)$ & $1(0.3 \%)$ & $8(2.7 \%)$ & $126(43.3 \%)$ & $156(53.6 \%)$ & 4.50 \\
\hline
\end{tabular}

Questionnaire, 2010

his affairs to Him after persistent efforts and Allah loves those who tawakkal (al-Quran (3):159). This finding proves that by reading Quranic verses, learning motivation improves. This is so because in al-Quran is found many verses which educate Muslims to stay motivated and avoid despair as despair is not a Muslim characteristic but a characteristic of unbelievers (al-Quran (12): 87). Al-Quran also motivates Muslims not to feel humiliated and sad but to feel honored as honor is from faith in Allah SWT (al-Quran (3):139). This shows Islam teaches Muslims not to be so humble as to be humiliated by others.

Another verse asserts that Allah SWT will not burden anyone with something which is beyond his capacity to overcome. This indirectly motivates Muslims to endeavor with persistence because Allah would not have given them responsibility beyond their capacity to deal with it (al-Quran (2):286). Through al-Quran it is clearly shown that Islam constantly motivates Muslims to realize that trials in life do not last forever. On the contrary, Allah promises that underlying each difficulty is reward of comfort. Islam educates the psyche of Muslims to persevere in the face of whatever hardship because after hardship there is comfort and joy (al-Quran (94):5-6). Establishing regular prayers improves learning motivation because one has faith in the promise of Allah SWT that those who establish prayers will receive good news of the reward in the hereafter, they will neither feel anxious nor sad (al-Quran (2):277). In addition, prayers performed with khusyu (humbly and conscientiously) help to bring peace of mind as is stated in al-Quran that in remembrance of Allah SWT, the heart will feel the tranquility (al-Quran (13): 28).

This discussion clearly shows that spiritual practice helps to improve learning motivation because exercises such as reading al-Quran, establishing regular prayers and tawakkal in Allah SWT encourage and motivate a person to abandon negative qualities such as despair, anxiety and sadness while relentlessly working hard in pursuit of success.
Table 4: Correlation between spiritual practice and student academic Achievement

\begin{tabular}{ll}
\hline Variables & r-value \\
\hline Learning-related spiritual practice & $0.262^{* * *}$ \\
Academic achievement & - \\
\hline
\end{tabular}

$* * \mathrm{p}<0.01$

addition, another objective of this research is to determine the relation between spiritual practice and student academic achievement. Research findings through the Pearson correlation test show a significant relation between spiritual practice and student academic achievement $(r=0.262 ; p<0.01)$. This finding explains that there is a significant correlation between spiritual practice and student academic achievement even though the correlation is weak. This finding is strengthened by a research conducted by Steward and Jo (1998) who find that adolescents with high religious spirituality are able to easily maintain psychological well-being and achieve the highest academic success. However, a quasi-experimental research by Hodge and Cuddeback (2010) proved that students who follow a release time (religious and moral activity class) program do not have a significant correlation with low academic scores. This means that student involvement in religious and moral programs does not influence their academic achievement. In addition, a study by Endang Pertiwi et al. (2009) finds that spiritual intelligence has a close relation to student academic achievement. Spiritual strength prevents negative acts and helps students to control their lazy attitude and other emotional upsets or disorders which can interfere with their academic achievement (Table 4).

In the Malaysian context, this finding may be strengthened by the admission of the best student for 2008 SPM (Malaysian Certificate of Education), Kamal and Hassan (2009) who scored A for all 20 subjects. She stated that one of the roots of her success in education is spiritual practice such as performing prayers on time, purifying the heart of mazmunah (negative qualities/traits), performing qiyam al-lail (solat tahajjud, hajat, taubat and istikharah), optional fasting on Mondays 
and Thursdays, performing solat dhuha every morning, selawat (invoking blessings) for the Prophet (PBUH) 1000 times each day and eating halal food which is not in doubt. Nik Nur Madihah (2009) explained the importance of qiyam al-lail in a student's life I am still trying to make qiyam al-lail a daily practice. Though I cannot get to do it everyday, I try to do it on some days in a week.

Even though, this research finds spiritual practice has an effect on student academic achievement, the correlation is not that strong. This shows that there are other factors, besides spiritual practice, needed by students to improve their academic performance, such as socio-economic factors, parents' educational level, family income, teachers' teaching styles and the study method of students themselves (Harb and El-Shaarawi, 2006; Considine and Zappala, 2002; Fraser and Roy, 2003).

\section{CONCLUSION}

Spiritual practice is an important aspect in the academic world of students. Spiritual practice such as solat hajat, qiyam al-lail, reading al-Quran and also congregational prayers are among the spiritual exercises frequently practised by students, specifically students of Islamic studies. In addition, there are some examples of spiritual support identified by respondents as helpful in improving learning motivation such as family support, tawakkal, 5 daily prayers, reading al-Quran and ability to control emotions and thoughts. This study also finds that spiritual practice has a significant correlation with student academic achievement $(r=0.262 ; p<0.01)$. Finally, it can be concluded that spiritual practice plays an important role in improving motivation and student academic achievement at FPI, UKM. Hence, spiritual practice should be emphasized in student life, particularly Muslim students and it should not be taken lightly or dismissed as not having a positive impact on motivation and academic achievement.

\section{REFERENCES}

Al-Ghazali, 2000. The Revival of Religious Sciences. Dar Al-Taqwa Li Al-Turath, London, UK.

Buchanan, M.T., 2009. The spiritual dimension and curriculum change. Int. J. Child. Spirituality, 14: 385-394.
Campbell, K.P., 2010. Transformative learning and spirituality: A heuristic inquiry into the experience of spiritual learning. Ph.D. Thesis, Capella University, USA.

Considine, G. and G. Zappala, 2002. Factors influencing the educational performance of students from disadvantaged backgrounds. Proceedings of the National Social Policy Conference, July 4-6, 2001, University of New South Wales, Sydney, pp: 91-107.

Daniliuk, A.I., A.M. Kondakov and V.A. Tishko, 2010. The spiritual and moral education of russia's school students. Russ. Educ. Soc., 52: 3-18.

Faiver, C.M., R.E. Ingersoll, E.M. O'Brien and C. McNally, 2000. Explorations in Counseling and Spirituality, Philosophical, Practical and Personal Reflections. 1st Edn., Brooks Cole, USA., ISBN: 978-0534575823, Pages: 224.

Fraser, W.J. and K. Roy, 2003. Factor influencing academic success or failure of first-year and senior university students: Do education students and lecturers perceive things differently? S. Afr. J. Educ., 23: 254-263.

Harb, N. and A. El-Shaarawi, 2006. Factors affecting students performance. J. Bus. Educ., 82: 282-290.

Hodge, D.R. and G.S. Cuddeback, 2010. Release time and academic outcomes: Do releasing students for religious or moral education negatively affect test score? J. Soc. Soc. Work Res., 1: 56-65.

Jankowski, P.J., 2002. Postmodern spirituality: Implications for promoting change. Counseling Values, 47: 69-79.

Kamal, M.N.N.N.M. and U.H.A. Hassan, 2009. The Heart Notes of Nik Nur Madihah, Difficulties is not obstacles to success. Hijjaz Records Publishing, Petaling Jaya.

Maher, M.F. and T.K. Hunt, 1993. Spirituality reconsidered. Counseling Values, 38: 21-28.

Revell, L., 2008. Spiritual development in public and religious schools: A case study. Religious Educ., 103: 102-118.

Saidy, E.P., A. Hassan, F.A. Rahman, H.A. Jalil, I.A. Ismail and S.E. Krauss, 2009. Influence of emotional and spiritual intelligence from the national education philosophy towards language skills among the secondary school. Eur. J. Soc. Sci., 9: 61-71.

Steward, R.J. and H. Jo, 1998. Does spirituality influence academic achievement and psychological adjustment of african american urban adolescents? http://catalogue.nla.gov.au/Record/5614444. 